\title{
The effects of Japanese economic performance on Indonesia
}

\author{
Hakan Berument ${ }^{\mathrm{a}, *}$, Nildag Basak Ceylan ${ }^{\mathrm{b}}$ and Bengisu Vural ${ }^{\mathrm{a}}$ \\ ${ }^{a}$ Department of Economics, Bilkent University, 06800, Ankara, Turkey \\ ${ }^{\mathrm{b}}$ Department of Management, Atilim University, 06836, Ankara, Turkey
}

This paper assesses how Japanese economic performance affects the Indonesian economy for the 1988 to 2004 period. The empirical evidence provided here suggests that Japanese growth appreciates the local currency in real terms, decreases the inflation and increases growth. As a side issue, we also documented that real exchange rate depreciation accelerates inflation and decreases growth in Indonesia.

\section{Introduction}

In a world which is structured as it is today, it is not possible to analyse an economy in isolation. One has to consider the effects of foreign countries' economic performance (especially their main trading partner's) as well when evaluating the domestic economy. Being aware of this fact, economists now focus more on this effect. Papers such as Burdekin (1989), Lastrapes and Koray (1990), Holman and Neumann (2002), Horvath et al. (1998), Backus et al. (1992), Stockman and Tesar (1995) documented crosscountry correlations among macroeconomic performances. The latter two point out positive correlations across countries between cyclical variations in output, as well as in other macroeconomic aggregates. ${ }^{1}$ Schmitt-Grohe (1998), one of the papers written on this topic, draws attention to the scale of the economies. Taking the effects of US economic performance on Canada into consideration, she claims that a shock directly affecting the output of a large country may affect a small country as well but the relationship does not work the other way around. Applying this to her case, she further argues that the macroeconomic variables (output, employment, investment, exports, imports, and terms of trade) of Canada, a small country compared to the US, respond to a positive shock in the US gross national product. In his study, Mackowiak (2006) investigated how many of the fluctuations of emerging markets in Asia and Latin America were attributable to external shocks, such as shifts in US monetary policy, by using a structural VAR model. His findings showed that less than $10 \%$ of the variation in emerging markets was attributable to the shocks in US monetary policy. Arora and Vamvakidis (2001) also investigated the impact of US growth on other countries. They found the impact significant considering the United States is a global trading partner.

In this paper, we attempt to reveal the effects of the economic performance of Japan on the exchange rate, output and inflation in Indonesia. A shock in a large economy (Japan) affects the small country's (Indonesia's) economic conditions if the large country is an important trading partner of the small country. In this sense, Japanese and Indonesian economies form a suitable small-large country pair as in the study of Schmitt-Grohe (1997), since Japan is the major trading partner of Indonesia.

In order to assess the effect of the economic performance of large countries on a small country, we set up a block recursive VAR similar to Cushman and Zha (1997). In particular, we specify the model such that the economic performance of a small country is

*Corresponding author. E-mail: berument@bilkent.edu.tr

${ }^{1}$ For a more extensive literature survey on this topic, see Backus et al. (1993). 
affected by the current and lag values of a large country but not vice versa. The empirical evidence provided in the paper suggests that higher growth in Japan appreciates the local currency in real terms, decreases inflation and increases growth for Indonesia. As a side issue, real exchange rate depreciation in Indonesia increases inflation and decreases growth. Findings on the effects of the real exchange rate are similar to what Kamin and Rogers (2000) found for Mexico, Akinlo and Odusola (2003) found for Nigeria, and Berument and Pasaogullari (2003) found for Turkey.

In the following section, the methodology is introduced. The presentation of the specifications of the model and the empirical evidence will be presented in the third section. The paper is concluded in the last section.

\section{Methodology}

While identifying the effect of the world economy's output on a small economy, we have used a structural vector autoregressive (SVAR) model similar to the one suggested by Cushman and Zha (1997). Specifically speaking, a block recursive model, where foreign economic performance is determined by its own dynamics (an AR process is used as a proxy) and Indonesian macroeconomic variables follow a three-variable VAR model, is constructed. Moreover, Japanese output affects the Indonesian economic performance as an exogenous variable. This four-variable VAR set-up differs from the conventional four-variable VAR system in the sense that none of the lags of Indonesian economic variables enter the Japanese output growth specification but Indonesian economic variables are affected by the current and lag values of Japanese income. In this specification, Japanese GDP growth is used as exogenous since it is not expected to be affected by contemporaneous shocks to the Indonesian economic variables such as inflation, real exchange rate and GDP. In our specification, the Japanese GDP is expected to capture the external developments that might have an effect on Indonesia's real exchange rate, inflation rate and GDP growth.

We used a three-variable VAR model that is similar to Kamin and Rogers (2000) and Berument and Pasaogullari (2003) to capture the dynamics of the Indonesian economy. Our VAR specification is formed by three endogenous variables with the

\footnotetext{
${ }^{2}$ See Sims (1986) and Gordon and Leeper (1994).
}

ordering as Indonesia real exchange rate, Indonesian inflation and output growth.

The advantages of utilizing a VAR model, instead of the conventional single equation model, are that VAR specification captures the dynamic relationships among the variables of interest and has a comparatively higher predictive power. The problem of the foreign (large) economy's income being affected by the variables of the domestic (small) one with their lags has been restricted by the construction of an identified structural block recursive VAR model.

\section{Model Specification}

Cushman and Zha (1997) specify the identified VAR model as follows:

$$
A(L) y(t)=\varepsilon(t)
$$

in which the $A(L)$ is an $m \times m$ matrix polynomial in the lag operator $\mathrm{L}, y(t)$ is the $m \times 1$ observations vector, and $\varepsilon(t)$ is the $m \times 1$ vector of structural disturbances. The specification of the model is shown in Equation 2.

$$
\begin{gathered}
y(t)=\left[\begin{array}{l}
y_{1}(t) \\
y_{2}(t)
\end{array}\right], \quad A(L)=\left[\begin{array}{cc}
A_{11}(L) & 0 \\
A_{21}(L) & A_{22}(L)
\end{array}\right], \\
\varepsilon(t)=\left[\begin{array}{l}
\varepsilon_{1}(t) \\
\varepsilon_{2}(t)
\end{array}\right] .
\end{gathered}
$$

The assumptions in this equation are that $\varepsilon(t)$ is uncorrelated with $y(t-j)$ for $j>0$ and $A(0)$ is nonsingular. Furthermore, $A_{12}(L)$ represents the block exogeneity, which is zero. Both contemporaneously and for lagged values, $y_{1}(t)$ is exogenous to the second block. The conventional Choleski normalization is used with the modified error bands of Bernanke et al. (1996) in the computation of the maximum likelihood estimation (MLE) and in the inference for the second block, since the MLE of the VAR model is not applicable to the identified VAR model with block exogeneity. ${ }^{2}$

We define the vectors of interest such that $y_{1}=[$ Foreign Income $]$ and $y_{2}=[$ Real Exchange rate, Inflation, Output growth] are the observation matrices and the lag order of the identified VAR model is 1, which is suggested by Bayesian information criteria. The order of the variables of the latter block is taken from Kamin and Rogers (2000) and Berument and Pasaogullari (2003). These assume that the real exchange rate affects inflation and domestic output growth contemporaneously, but is not affected by 
those two variables contemporaneously. Inflation affects output growth but is not affected by real exchange rate contemporaneously. Output growth is affected by the preceding variables contemporaneously. Last, all these variables are affected by each other with lag.

In our work, we have examined the interrelationships among inflation, growth and the real exchange rate in Indonesia. We have used the real exchange rate, the real GDP, inflation and the Japanese GDP growth in our model. The real exchange rate is the rupiah per US dollar. The inflation rate is the logarithmic first difference of the Consumer Price Index of Indonesia. The growth rate is the logarithmic first difference of the real GDP.

In order to address the seasonality in the data, we used dummy variables. The sample period covers quarterly data from 1988:I to 2004:I. The data used are quarterly due to the availability of GDP data. All data, except the Indonesian GDP, were obtained from the International Financial Statistics (IFS) database of the IMF. The data for the Indonesian GDP are available on the website of the Bank of Indonesia (http://bi.go.id).

In Figs 1 and 2, the impulse responses of the VAR model, which include the Japanese output, real exchange rate, output and inflation using 1 lag for 12 periods are presented. The impulse response functions were obtained by a bootstrap procedure and the confidence intervals of impulse responses are $90 \%$.

Before discussing the effects of the foreign income on domestic economy, we first assess the effect of the real exchange rate on Indonesia. In Fig. 1, it can be observed that a positive real exchange rate shock (real depreciation) increases the inflation for all 12 periods. Moreover, the magnitude is statistically significant in these periods. The effect of the real exchange rate on output is statistically significant and negative. The effect of the shock on the real exchange rate is also positive and statistically significant for the whole time span. One finding worth noting is that the effect of the shock is permanent for all of the three endogenous variables. Our findings show parallelism with the findings of Kamin and Rogers (2000), Akinlo and Odusola (2003) and Berument and Pasaogullari (2003), which support the contractionary devaluation hypothesis for Mexico, Nigeria and Turkey, respectively.

The effect of Japanese output on Indonesian output, inflation rate and real exchange rate can be observed in Fig. 2. As can be seen from the figure, a one-standard deviation shock to Japanese output appreciates the Indonesian real exchange rate. The effect of the shock is statistically significant at the $5 \%$
Indonesian exchange rate

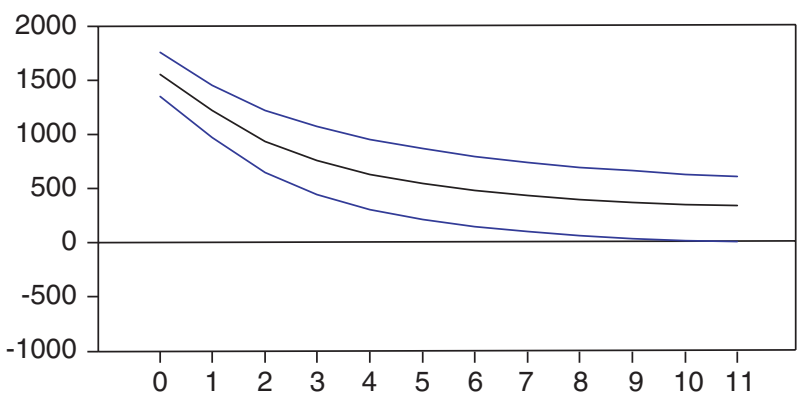

Indonesian inflation rate



Indonesian output

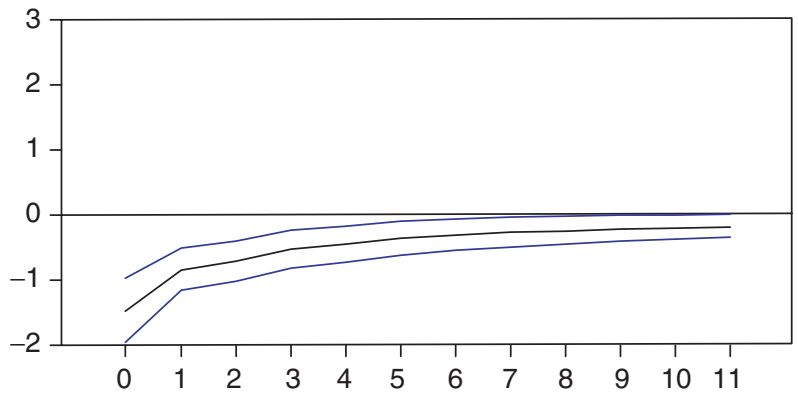

Fig. 1. Impulse responses to a shock in Indonesian exchange rate

level in the first period. The effect of the shock on Indonesian inflation is statistically significant and negative in the first period. The response of Indonesian growth is positive and significant contemporaneously in the second period. One-standard deviation shock given to Japanese output was found to affect the Indonesian exchange rate, growth and inflation rate.

\section{Conclusion}

In this study, we have investigated the effect of the Japanese GDP on the economic performance of Indonesia as regards three variables: real exchange rate, inflation and growth. A block recursive VAR model was used, allowing Japanese economic 
Japanese GDP



Indonesian exchange rate



Indonesian inflation rate

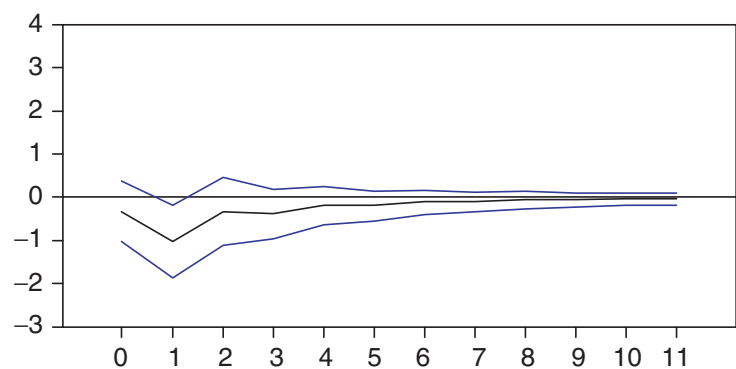

Indonesian growth

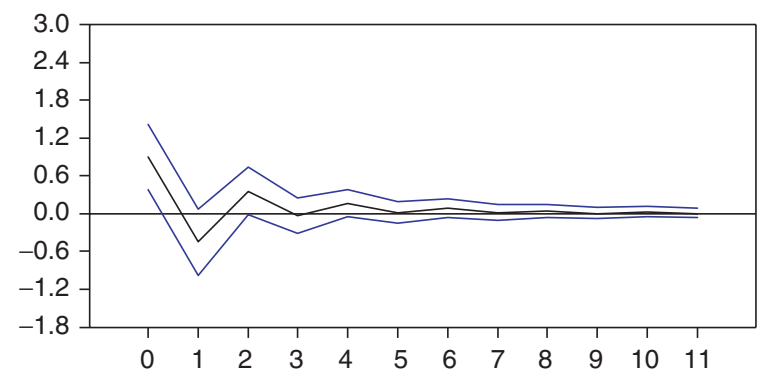

Fig. 2. Impulse responses to a shock in Japanese GDP

performance to affect Indonesian economic performance but not vice versa. After employing the VAR model for the 1988:I-2004:I period, which includes the Japanese GDP and the Indonesian real exchange rate, inflation and output, we find that a onestandard deviation shock to Japanese GDP growth appreciates the local currency in real terms, decreases inflation and increases growth for Indonesia. Moreover, we find the response of output is negative and permanent after a real devaluation and this devaluation is inflationary.

\section{References}

Akinlo, A. E. and Odusola, F. (2003) Assessing the impact of Nigeria's naira depreciation on output and inflation, Applied Economics, 35, 691-703.

Arora, V. and Vamvakidis, A. (2001) The impact of US economic growth on the rest of the world: how much does it matter? IMF Working Paper WP $/ 01 / 119$.

Backus, D., Kehoe, P. J. and Kydland, F. E. (1993) International business cycles, Journal of Political Economy, 100, 745-75.

Backus, D., Kehoe, P. J. and Kydland, F. E. (1993) International business cycles: theory vs. evidence, Quarterly Review of the Federal Reserve Bank of Minneapolis, 17, 14-29.

Bernanke, B. S., Hall, R. E., Leeper, E. M., Sims, C. and Zha, T. (1996) What does monetary policy do?, Brookings Papers on Economic Activity, 2, 1-78.

Berument, H. and Pasaogullari, M. (2003) Effects of the real exchange rate on output and inflation: evidence from Turkey, Developing Economies, 41, 401-35.

Burdekin, R. C. K. (1989) International Transmission of U.S. macroeconomic policy and the inflation record of Western Europe, Journal of International Money and Finance, 8, 401-23.

Cushman, D. O. and Zha, T. (1997) Identifying monetary policy in a small open economy under flexible exchange rates, Journal of Monetary Economics, 39, 433-48.

Gordon, D. B. and Leeper, E. M. (1994) The dynamic impacts of monetary policy: an exercise in tentative identification, Journal of Political Economy, 102, $1228-47$.

Holman, J. A. and Neumann, R. M. (2002) Evidence on the cross-country transmission of monetary shocks, Applied Economics, 34, 1837-57.

Horvath, J., Kandil, M. and Sharma, S. (1998) On the European monetary system: the spillover effect of German shocks and disinflation, Applied Economics, 30, 1585-93.

Kamin, S. B. and Rogers, J. H. (2000) Output and the real exchange rate in developing countries: an application to Mexico, Journal of Development Economics, 61, 85-109.

Lastrapes, W. D. and Koray, F. (1990) International transmission of aggregate shocks under fixed and flexible exchange rate regime: United Kingdom, France and Germany, 1959 to 1985, Journal of International Money and Finance, 9, 402-23.

Mackowiak, B. (2006) External shocks, US monetary policy and macroeconomic fluctuations in emerging markets, Humbolt University, Mimeo.

Schmitt-Grohe, S. (1998) The international transmission of economic fluctuations: effects of US business cycles on the Canadian economy, Journal of International Economics, 44, 257-87.

Sims, C. A. (1986) Are forecasting models usable for policy analysis?, Quarterly Review of the Federal Reserve Bank of Minneapolis, 10, 2-16.

Stockman, A. C. and Tesar, L. L. (1995) Tastes and technology in a two-country model of the business cycle: explaining international comovements, American Economic Review, 85, 197-221. 